THURSDAY, JUNE 16, I $88 \mathrm{r}$

\section{THE STORAGE OF ELECTRIC ENERGY}

I AM continuing my experiments on the Faure accumulator with every-day increasing interest. I find $M$. Reynier's statement, that a Faure accumulator, weighing 75 kilograms ( 165 lbs.) can store and give out again energy to the extent of an hour's work of one-horse power (2,000,000 foot-pounds) amply confirmed. I have not yet succeeded in making the complete measurements necessary to say exactly what proportion of the energy used in the charging is lost in the process of charging and discharging. If the processes are pushed on too fast there is necessarily a great loss of energy, just as there is in driving a small steam-engine so fast that energy is wasted by "wire-drawing" of the steam through the steam pipes and ports. If the processes are carried on too slowly there is inevitably some loss through local action, the spongy lead becoming oxidised, and the peroxide losing some of its oxygen viciously, that is to say, without doing the proper proportion of electric work in the circuit. I have seen enough however to make me feel very confident that in any mode of working the accumulator not uselessly slow, the loss from local action will be very small. I think it most probable that at rates of working which would be perfectly convenient for the ordinary use of fixed accumulators in connection with electric lighting and electric transmission of power for driving machinery, large and small, the loss of energy in charging the accumulator and taking out the charge again for use will be less than to per cent. of the whole that is spent in charging the accumulator : but to realise such dynamical economy as this prime cost in lead must not be stinted. I have quite ascertained that accumulators amotnting in weight to three-quarters of a ton will suffice to work for six hours from one charge, doing work during the six hours at the uniform rate of one-horse-power, and with very high economy. I think it probable that the economy will be so high that as much as 90 per cent. of the energy spent in the charge will be given out in the circuit external to the accumulator. When, as in the proposed application to driving tramcars, economy of weight is very important, much less perfect economy of energy must be looked for. Thus, though an eighth of a ton of accumulators would work very economically for six hours at one-sixth of a horse-power, it would work much less economically for one hour at one horse-power ; but not so uneconomically as to be practically fatal to the proposed use. It seems indeed very probable that a tramcar arranged to take in, say $7 \frac{1}{2} \mathrm{cwt}$. of freshly-charged accumulators, on leaving head-quarters for an hour's run, may be driven more economically by the electric energy operating through a dynamo-electric machine than by horses. The question of economy between accumulators carried in the tramcar, as in M. Faure's proposal, and electricity transmitted by an insulated conductor, as in the electric railway at present being tried at Berlin by the Messrs. Siemens, is one that can only be practically settled by experience. In circumstances in which the insulated conductor can be laid, Messrs. Siemens' plan will undoubtedly be the Vor. $\operatorname{xxtv}-$ No. 607 most economical, as it will save the carriage of the weight of the accumulators. But there are many cases in which the insulated conductor is impracticable, and in which M. Faure's plan may prove useful. Whether it be the electric railway or the lead-driven tramcar, there is one feature of peculiar scientific interest belonging to electrodynamic propulsion of road carriages. Whatever work is done by gravity on the carriage going down hill will be laid up in store ready to assist afterwards in drawing the carriage up the hill, provided electric accumulators be used, whether at a fixed driving station or in the carriage itself.

University, Glasgow, June 13

WILLIAM THOMSON

\section{THE LIFE OF WHEWELL}

The Life, and Selections from the Correspondence, of William Whewell, D.D., late Master of Trinity College, Cambridge. By Mrs. Stair Douglas. (C. Kegan Paul and Co., r88r.)

$T$ is now about four years since the first instalment of I a biography of the late Dr. Whewell was published. These volumes, admirably edited by Mr. Todhunter, give us a brief outline of his history, but consist chiefly of a most valuable analytical account of his writings and a selection from his literary and scientific correspondence. In the preface a more complete memoir of Dr. Whewell's personal and domestic history is announced as in preparation. The present volume, edited by Dr. Whewell's niece, Mrs. Stair Douglas, fulfils the promise then given. The preface explains the long interval-fourteen yearswhich has elapsed since Dr. Whewell's death. A series of untoward events have continued to retard publication. From various causes much delay occurred before the exact plan of the work was determined and the subjects apportioned. At first it was hoped that what may be called the academic life of Dr. Whewell would be undertaken by Mr. Aldis Wright, the present Bursar of Trinity College. But the pressure of heavy and unavoidable engagements has precluded him from proceeding with the task. Mrs. Douglas then endeavoured to work the materials into the selections from Dr. Whewell's personal correspondence which she had nearly completed, with the assistance of Mr. J. Lemprière Hammond, Fellow of Trinity, and one of Dr. Whewell's executors. Before this was accomplished she was deprived of his invaluable aid by his lamented and untimely death. Thus some portions of the present work are a little incomplete. Still, as these are generally of a rather technical nature, and more interesting to members of the University than to the general reader, their absence probably will not be very widely felt. We may be allowed to express our admiration at the tact and good taste with which Mrs. Douglas has executed her task. She allows Dr. Whewell as far as possible to speak for himself, connecting his letters generally with only such brief biographical paragraphs as are necessary for a connected and intelligible narrative. There is little comment and no attempt at the fulsome praise with which biographies are often disfigured. Her descriptions, though brief, are often graphic, while the letters enable us to see the Master of Trinity as he appeared to the inner circle of intimate friends and loved relations.

of his vast and varied knowledge it is almost needless 
now to speak. Suffice it to say that the letters now published contain additional testimony to the truth of $\mathrm{Mr}$. Todhunter's remark in his preface to the volumes mentioned above: "I do not think adequate justice can be rendered to Dr. Whewell's vast knowledge and power by any person who did not know him intimately, except by the examination of his extensive correspondence; such an examination cannot fail to raise the opinion formed of him by the study of his published works, however high that opinion may be."

The letters, however, in the present volume, as might be expected, bring out their author in a light which is to many new and unexpected. To most persons that broad forehead with its massive brow seemed indicative of intellectual strength almost gigantic ; the square shoulders, strong bones and muscles, the swinging gait-with which as he swept along he seemed to shoulder aside weaker men by the very waft of his passing-told of irresistible force of will and energy of purpose; tenderness of heart seemed improbable in one of such Titanic mould; one deemed him a "man of iron," who, had he chosen a field other than literature and science, might also have been one of blood; but, as we shall presently see, underneath that rough exterior there was a warm and affectionate heart concealed.

Of the childhood of William Whewell but few particulars are recorded. A master-carpenter's son at Lancaster, he was on the point of quitting the Blue Coat School in that town to be apprenticed to his father, when -by a mere chance as it seemed-the head-master of the Grammar School entered into conversation with the boy, and was so struck by his abilities that he persuaded the father to let his son come to that school, gencrously offering to give him both books and instruction. According to Prof. Owen-probably his sole surviving schoolfellow -the lad's indomitable spirit soon manifested itself, as well as his appetite for work. The latter indirectly raised the standard of the school lessons, and the other boys threatened to "wallop" him as the penalty for preparing more than twenty lines of Virgil. Even then however this was more easily said than done, and the "wallopers" got as good as they gave, until public opinion in the school decided that it was unfair for more than two boys to attack him at once- "after the fate of the first pair, a second was not found willing." Once only did Whewell shock the moral feelings of his revered master, and that was when an undergraduate at Trinity. The crime shall be told in the master's own words: "He has gone and got the Chancellor's gold medal for some trumpery poem, 'Boadicea,' or something of that kind, when he ought to have been sticking to his mathematics. I give him up now. Taking after his poor mother, I suppose." (She had occasionally contributed to the "Poet's Corner" of the local newspaper.) Mrs. Owen, to whom this complaint was made, pacified the worthy man by remarking that "young men must have some amusement, and this seemed to be a very innocent one."

Notwithstanding Dr. Whewell's strong frame he appears to have suffered from some constitutional delicacy when a lad. His mother-evidently a woman of ability and culture above her station-died when he was thirteen; his father only survived to see him take a degree. A sister also died young; and of his three brothers two died in infancy and the other at the age of nine. Talent was evidently hereditary in the family, for the little brother, at seven years old, had begun to write English verses, and one of his sisters habitually. wrote poems. Of all three of the latter, he says, when referring to his prize poem, in a letter to his father, "I am happy in having sisters who all of them have, I think, a more rational taste for poetry and literature of all kinds than any other girls in the same circumstances."

It is very interesting to note the gradual change in these letters. We see in them not only the unfolding of his great intellectual powers as evidenced by the widening circle of interests, but also the gradual expanding of the moral nature. At first those addressed to his relations and more intimate friends are a little stiff and cold, but as sorrows succeed one another the religious element in Dr. Whewell's character becomes more conspicuous, and the later letters are marked by a depth of tenderness surprising to those who only knew him slightly. He was devotedly attached to his first wife, and almost heartbroken by her loss. In one letter he describes himself as taking no pleasure in success now that she was gone, and tells his niece how, while he sat as Vice-Chancellor in the Senate-house conferring degrees, he felt so lonely and miserable that the tears kept trickling down his face ; so unlikely a thing in a Vice-Chancellor in his chair that probably nobody saw it. I hope so." The writer of this article, who received his degree on that occasion, well remembers some of his friends commenting on the Vice-Chancellor's obvious "sourness" of manner, and wondering whether he was disgusted at the Senior Wrangler being a man of a rival college. We little thought that this was " none other than sorrow of heart." After some time Dr. Whewell married again, his second wife being Lady Affleck, sister of his friend Robert Leslie Ellis. In her companionship he found great happiness, but after about seven years of married life he was again left alone. This time he appeared unable to rally from the bereavement ; "the future which intervened between him and the grave dismayed him by its dark desolation." After this he visibly declined; the torpor of age began to steal over his faculties, and many thought that the years of waiting would not be very many ; but they were briefer than any expected. While still comparatively vigorous, a fall from his horse caused fatal injury to the brain, and after lingering for a few days, happily without much suffering, he died on March 6, 1866.

"While life was ebbing fast away on that last morning, blinds and curtains were drawn wide apart in compliance with his wish that he might see the sun shine on the Great Court of Trinity, and he smiled as he was reminded that he used to say the sky never looked so blue as when seen fringed with its turrets and battlements. Almost to the last he was conscious, and the last words intelligibly uttered, when the striking of the clock roused him as day dawned, were, 'The Eternal God is my refuge, and underneath are the everlasting arms.' "

The extraordinary comprehensiveness and versatility of Dr. Whewell's mind is fully depicted in the letters published in Mr. Todhunter's volume, but it is brought out no less, perhaps even more, graphically by some of the brief allusions in his familiar correspondence. This, for example, is one taken from a letter to his sister: "Besides my usual employments [as College Tutor and 
Professor of Mineralogy] I have to go to London two days every fortnight as President of the Geological Society, and am printing a book which I have not yet written ["The History of the Inductive Sciences"], so that $I$ am obliged often to run as fast as $I$ can to avoid the printers riding over me, so close are they at my heels. I am, in addition to this, preaching a course of sermons before the University ; but this last employment, though it takes time and thought, rather sobers and harmonises my other occupations than adds anything to my distraction." He seemed to be able to turn his hand to anything, and, like a dexterous conjuror, play with half-adozen balls at once. Pendulum experiments, theories of the tides, mathematical problems, crystallographic fcrmulæ metaphysics, and various subjects in moral philosophy, classics, modern languages, architecture, geology, with plenty of work in general literature, all make up what we may call in the best sense "farrago libelli." These letters also bring out very clearly another characteristic of $\mathrm{Dr}$. Whewell's mind. He was essentially cautious in regard to change-an advocate of reformation rather than of renovation; in science a systematiser rather than a discoverer; like a navigator who explored to the full the uninvestigated coasts of the Old World, rather than one who steered out into the open ocean in the hope of discovering a New World. This was no doubt partly due to his mathematical training and academic habits of life-but it is very rare, perhaps impossible, to find a memory of extraordinary tenacity and a life essentially studious, combined with originality in one of its highest forms. That requires a good deal of mental fresh air, and is apt to droop a little if too much confined to the atmosphere of a library. This is especially evident in Dr. Whewell's remarks upon the "Vestiges of Creation" and in his essay on the "Plurality of Worlds." The same tone of mind is very conspicuous in his attitude towards the question of University Reform. He was a vigorous opponent of the abuses of private tuition, a zealous advocate of progress in every department of learning, deeply anxious for the improvement of the Classical and Mathematical Tripos examinations, and to him more than to any other single man the recognition of the Natural and Moral Sciences as branches of academic study is due. But he was antagonistic-almost bitterly so-to the appointment of the Royal Commission of 1856 and of its successor, and was hostile in many respects to the changes-now almost universally acknowledged to have been on the whole very beneficial-which were introduced by the statutes of 1859-61. His great hope and desire was that the University should be allowed to reform itself, and be spared any interference from without. That he should have entertained this hope after so many years of academic labour is perhaps the strongest proof of his sanguine temperament.

We must now part from this interesting volume. Perhaps-like the portrait prefixed to it-it slightly fails in depicting the characteristic ruggedness of the man, but it does much to show him as he was to those near and dear to him as well as to the world-a man of immense intellectual power, of intense energy and industry, of high purpose and simple piety, a hard hitter in conflict and a lover of the shout of battle, but too magnanimous to bear ill-will, whether in defeat or victory. Besides this he was a munificent benefactor to his College and his University : one to whom both must long be grateful, and of whom both may well be proud, as having filled a great position in the world of science and literature, and especially as being "the man" (in the opinion of a most competent judge) "to whom, more than to any other single man, the revival of philosophy in Cambridge is due." T. G. BONNEY

\section{OUR BOOK SHELF}

Inorganic Chemistry. Adapted for Students in the Elementary Classes of the Science and Art Department. By Dr. W. B. Kemshead, F.R.A.S., F.G.S. Enlarged edition, revised and extended. (London and Glasgow : William Collins, Sons, and Co., Limited.)

THrs work is a typical one. While containing much that is useful and fairly satisfactory, especially from an examination point of view, the whole tendency of the book, considered as an elementary treatise on a branch of natural science, must be strongly condemned.

The leading facts concerning the better-known nonmetallic elements and compounds are succinctly stated; the principal reactions of formation and decomposition of these bodies-especially those reactions which unfortunately must be "got up " for examination purposes-are arranged in the form of equations; and the simpler arithmetical applications of such equations are illustrated by fully worked-out examples. But chemistry is more than this: facts must be connected together by principles; the connection between fact and theory, and between theory and fact, must be revealed; these two must not be regarded as synonymous, but as mutually dependent; and the reasoning by aid of which theoretical conclusions are reached must be clearly indicated. Chemistry is neither a system of dogmatic assertions nor an accumulation of shibboleths, by the skilful use of which an examiner may make havoc among the Ephraimites crowding to the Jordan of Examination, but a living science.

The principle which is most largely used (or rather mistised) in Dr. Kemshead's book is that of Valency; but valency in the hands of this author is, deprived of its value as a scientific theory, and becomes an accumulation of fanciful speculations. The basis of the present work is evidently Dr. Frankland's "Lecture Notes"; hence probably the success of the book in preparing examinees for South Kensington (the present is a second and enlarged edition); and is not such success after all of more importance than training chemists or disciplining the mental powers of youth?

The theory of valency is based on the wider molecular theory of matter, which was preceded by the atomic theory of Dalton, itself a development from that system of chemical notation which rested on the combining weights of the elementary bodies. Now it is clear, from many passages, that the author of this book has failed to distinguish combining weights from atomic weights, and atomic from molecular weights : thus on $p$. 13 we read "these proportions by weight [i.e. from the context, these proportions in which "substances unite together chemically"] when reduced to their lowest relative value, and expressed with reference to that of hydrogen, which is usually taken as unity, are called the atomic weights, or combining numbers of the elements." Again, on p. 26, "the combining weight of hydrogen being $I$, that of oxygen becomes 16 ; of nitrogen, 14 ; of carbon, I2," \&c. But combining weights are not synonymous with atomic weights, and the combining weight of oxygen happens to be 8 , of carbon 3 , and of nitrogen 4.66 . The formula weights of compounds are constantly referred to as "atomic and molecular weights." We have such formulæ as $\left(\mathrm{NH}_{4} \mathrm{O}\right)_{2}, \mathrm{CuO}_{2}, \& \mathrm{c}$, stated to be molecular formula; 